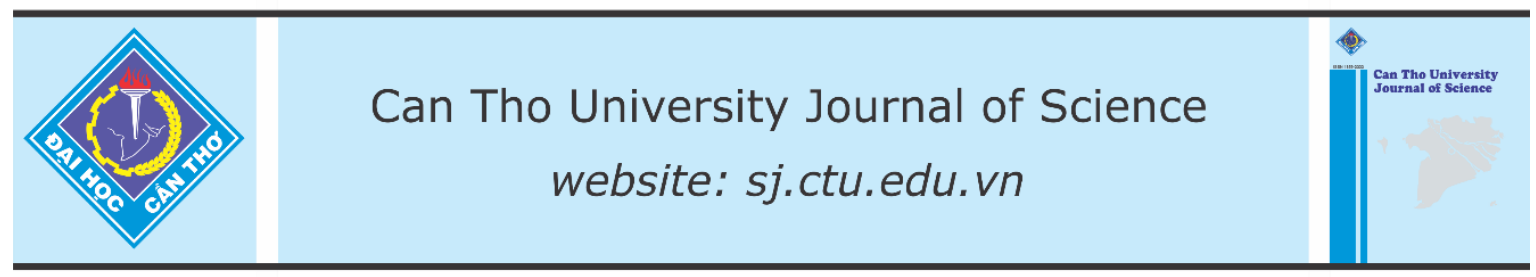

DOI: $10.22144 /$ ctu.jen.2021.011

\title{
Effects of salinity on growth performance, survival rate, digestive enzyme activities and physiological parameters of striped catfish (Pangasianodon hypophthalmus) at larval stage
}

Nguyen Thi Kim Ha ${ }^{1}$, Nguyen Tinh Em ${ }^{1}$, Nguyen Minh Ngoc $^{2}$, Yasuaki Takagi ${ }^{3}$,

Nguyen Thanh Phuong ${ }^{1}$ and Do Thi Thanh Huong ${ }^{1 *}$

${ }^{1}$ College of Aquaculture and Fisheries, Can tho University, Viet Nam

${ }^{2}$ Can Tho City Fisheries Agency, Can Tho City, Viet Nam

${ }^{3}$ Hokkaido University, Japan

*Correspondence: Do Thi Thanh Huong (email: dtthuong@ctu.edu.vn)

\section{Article info.}

Received 22 Feb 2021

Revised 07 Apr 2021

Accepted 04 Jun 2021

\section{Keywords}

Growth, physiological parameters, salinity, striped catfish

\begin{abstract}
The present study was to investigate the effects of different salinities $(0$ (control), 3, 6, 9, 12, 15\%o) in striped catfish (Pangasianodon hypophthalmus) at larvae stage. Four-hundred individuals were randomly distributed to each 500-L composite tank (containing 250-L water) in triplicates. After 60 days, fish was sampled to determine survival rate, growth performance, hematological parameters, stress response indicators, and enzymatic activities. The results showed that the survival rate was highest in $6 \%$ o $(60.9 \%)$ and lowest in $15 \%$ o $(1.25 \%)(p<0.05)$. Fish exposed to salinities from 0 to $9 \%$ showed an increasing trend in growth. The osmolality of fish reared in 9 and 12\%o was significantly higher than that in the lower salinities $(p<0.05)$. Similarly, concentrations of $\mathrm{Na}^{+}, \mathrm{K}^{+}$, and $\mathrm{Cl}^{-}$increased remarkably at high salinities. Chymotrypsin and trypsin activities were reduced by increased salinities $(p<0.05)$, which were lowest at $15 \%$ o $69.2 \pm 2.46 \mathrm{U} / \mathrm{min} / \mathrm{mg}$ protein and $1.46 \pm 0.01 \mathrm{mU} / \mathrm{min} / \mathrm{mg}$ protein, respectively). Stress indicators such as glucose and cortisol concentrations were not significantly depended on the salinity in the range of 0 to $12 \%$. Striped catfish larvae showed an adaptable response to high salinity and the appropriate salinity range for larvae rearing was below $6 \%$.
\end{abstract}

\section{INTRODUCTION}

Striped catfish (Pangasianodon hypophthalmus) is an important aquaculture species in the Mekong Delta, Vietnam. This species has a long historical development of culture. The total cultured area, production, and export turnover of this species reached 5,485 ha, 900,429 tons, and 1.12 billion USD, respectively (Vietnam Association of Seafood Exporters and Producers [VASEP], 2020). The main production areas are in Dong Thap and An Giang provinces and Can Tho city. In recent years, salinity intrusion and temperature increase due to climate change have seriously affected animal and human living. The increase of temperature and sea-level rise have been mostly concerned in this delta; the sea level rise was projected to be $75 \mathrm{~cm}(52-106$ $\mathrm{cm})$ at the end of this century causing salinity intrusion into the inland (Ministry of Natural Resources and Environment [MONRE], 2016). Nguyen et al. (2014) built a model that evaluated the effect of sealevel rise and saltwater intrusion for three sea-level rise scenarios $(+30,+50$ and $+75 \mathrm{~cm})$ on the striped catfish culture industry, the results revealed that several coastal regions such as Can Tho, Soc Trang, and Ben Tre provinces were reported to have negative 
impacts by saltwater intrusion at different levels. In teleost, osmoregulation capacity when exposed to different salinities is one of the most important markers that directly decides their tolerances and living habits (Varsamos et al., 2005). Previous research on striped catfish found that salinity affected embryonic development, physiological responses, growth rate and survival at juvenile stages (Huong \& Quyen, 2012; Phuc et al., 2014). In terms of hematology, the increase of salinity caused the decrease of blood hematocrit (Hosseini et al., 2011). Acute exposure to salinity also significantly reduced the number of red blood cells in striped catfish (Ane et al., 2019). Regarding stress impacts, a hyperosmotic environment increases stress indicators as glucose and cortisol in a short term, but fish can adapt to the changes in long-term exposure (Thao et al., 2013). Besides, it is found that salinity cause increasing digestive enzymatic activities in some euryhaline species. Particularly, American shad (Alosa sapidissima) incubated and reared in freshwater before experimentation showed higher activities in some digestive enzymes in fish subject to $21 \%$ compared to the corresponding fish in freshwater and lower salinity conditions (Hamed et al., 2016; Tsuzuki et al., 2007). Salinity up to $9 \%$ also increased the amylase activities in snakehead fish (Channa striata) but that was decreased at 12 and 15\% (Tinh, 2013). Previous findings indicate that hyperosmotic environment affects growth performance and physiological responses. However, the knowledge on the effects of salinity on growth, hematological, physiological and enzymatic activities of fish at the larvae stage has been unknown largely, especially on striped catfish. Therefore, this research was conducted to evaluate the responses of fish exposed to elevated salinity conditions to provide knowledge for the technical adaptation of striped catfish under the context of salinity change.

\section{METHODS}

\subsection{Materials}

Striped catfish larvae of 24-hour post-hatching were collected from the hatchery of Viet-Uc company (in An Giang province). The larvae were acclimated 1day in-tank conditions. The high salinity seawater (80-90\%o) was treated with $30 \mathrm{mg} / \mathrm{L}$ chlorine and diluted with fresh water to desirable salinities.

\subsection{Determination of salinity tolerance}

The experiment was set up in 20-L plastic container (containing 5-L water) in triplicate. Twenty larvae were stocked into each container. Salinity was increased 1\%o per 3 hours until fish mortality was around $50 \%$. This salinity level was considered as salinity tolerance of larvae.

The results showed that the larvae reduced behavior in salinity of $13 \%$ and it completely stopped at $14 \%$. The mortality was $10 \%$ and $50 \%$ when the salinity increased to $15 \%$ and $17 \%$, respectively. Therefore, the salinity tolerance in striped catfish larvae was estimated at $17 \%$. Based on the results, 6 levels of salinity $(0,3,6,9,12,15 \%)$ were chosen for the next experiment.

\subsection{Effects of salinity on growth rate from larvae to fry}

\subsubsection{Experimental design}

The experiment was organized in a completely randomized design with triplicate of 6 treatments including 0 (control), 3, 6, 9, 12, 15\% in 500-L (containing $250-\mathrm{L}$ water) composite tank. The stocking density was 400 larvae per tank. The salinity was increased $1 \%$ per 8 hours, the higher salinity treatments were initiated before the lower salinities to have all treatments reach desirable salinity at the same time. The experiment was implemented in 60 days.

Fish were fed thrice daily at 7:00, 12:00, and 17:00 hour. Larvae of 24-36 hours post-hatching (yolk-sac absorption completed) were fed rotifer (Brachionus plicatils) with a density of $500 \mathrm{ind} / \mathrm{mL}$. Moina was then replaced by rotifer from the day 3 to 15 with a density of 16 to $20 \mathrm{ind} / \mathrm{mL}$. Fish were fed with powdered commercial feed during day 15 to 30 (42\% protein); crumble feed during day 30 to 45 (42\% protein), and $0.6 \mathrm{~mm}$ to $0.8 \mathrm{~mm}$ pellet feed during day 45 to 60 (35\% to $40 \%$ protein). The feed used for experiment from the Cargill company.

All tanks were continuously aerated during the experiment. During the weaning period from live feed to commercial feed (30-day post-stocking), waste from the tank bottom were siphoned in combination with $30 \%$ water exchange every 3 days. Water quality such as dissolved oxygen (DO), $\mathrm{pH}$, and temperature were checked twice daily in the morning and afternoon. Nitrite $\left(\mathrm{NO}_{2}^{-}\right)$and TAN concentrations were weekly recorded using methods (Griess llosvay and Diazonium and Indophenol blue).

\subsubsection{Sampling methods}

Fish length and weight were measured from 10 fish/tank on day 30 and 45 . All fish were weighed at the end of the experiment (day 60). Fish growth indicators were calculated for weight gain (WG), daily 
weight gain (DWG) and specific growth rate (SGR). Mortality was daily recorded to calculate survival rate. Blood samples were also collected at day 60 . Heparinized 1 -mL syringe (needle $26 \mathrm{G} \times 1 / 2$ ") was used to draw blood from the caudal vein less than 3 min to avoid stressed fish (Abdel-Tawwab et al., 2005). After that immediately red blood cell, white blood cell, hemoglobin and hematocrit were evaluated; the remaining blood sample was centrifuged at $6,000 \mathrm{rpm}$ in 6 minutes at $4^{\circ} \mathrm{C}$ to collect serum to analyze osmolality, sodium $\left(\mathrm{Na}^{+}\right)$, chloride ion $\left(\mathrm{Cl}^{-}\right)$ concentration, glucose and cortisol. The stomach and intestine were also collected (after drawing blood) to analyze enzymatic activities including trypsin, amylase, pepsin, and chymotrypsin.

\subsubsection{Sample analysis methods}

\section{Physiological responses}

Red blood cell (WBC) counts were determined by diluting blood into Natt-Herrick and counting on Neubauer hemocytometer (Huong \& Tu, 2010). Total leukocytes were counted up to 1,500 cells on blood smear after natural drying, methanol fixing, and Wright and Giemsa staining. Hemoglobin was measured by Drabkin solution (Oser, 1965). Fresh heparinized blood was centrifuged in microhematocrit tubes at $12.000 \mathrm{~g}$ for $3 \mathrm{~min}$ to calculate hematocrit based on the volume rate of serum and blood cells. The plasma osmolality was analyzed by using a Micro Osmometer (Advanced Instruments Model 3300). Ion $\mathrm{Na}^{+}$was measured by a Flame Photometer (Sherwood model 420, Cambridge, UK). Ion $\mathrm{Cl}^{-}$ was measured by a chloride titrator (Model 926S MK II, Sherwood, Cambridge, UK). Glucose concentration was measured by following the method of Hugget and Nixon (1957). Regarding digestive enzymatic activities, the samples were thawed on ice and homogenated with the buffer $\mathrm{KH}_{2} \mathrm{PO}_{4} 20 \mathrm{mM}$ and $\mathrm{NaCl} 6 \mathrm{mM}$ and $\mathrm{pH}$ 6.9. The mixture was centrifuged in $30 \mathrm{~min}$ at $4,200 \mathrm{rpm}$ and $4^{\circ} \mathrm{C}$ and then supernatants were collected and stored at $-80^{\circ} \mathrm{C}$ for analyses. Trypsin and amylase were measured using the methods of Tseng et al. (1982) and Bernfeld (1951), respectively, while chymotrypsin and pepsin activities were measured by following the method of Worthington (1982). Protein was determined using Biorad protein assay. Enzyme activities are expressed as $\mathrm{U} \mathrm{mg}$ protein ${ }^{-1} \mathrm{~min}^{-1}$.

Survival and growth parameters

Survival rate $(\mathrm{SR}, \%)=($ No. of fish at the end of the experiment/No. of initial fish) x 100

Daily weight gain $(D W G, g /$ day $)=($ Wf-Wi $) / t$

Specific growth rate $(\mathrm{SGR}, \% /$ day $)=[(\mathrm{Ln}(\mathrm{Wf})-$ $\mathrm{Ln}(\mathrm{Wi})) / \mathrm{t}] \mathrm{x} 100$

Where: $\mathrm{W}_{\mathrm{i}}$ is the initial weight $(\mathrm{g})$; Wf is the final weight $(\mathrm{g})$, and $\mathrm{t}$ is the experimental time (day).

\subsection{Statistical methods}

All the data were subjected to statistical analysis including standard deviation (SD) and mean using Excel 2016. One-way analysis of variance (ANOVA) together with DUNCAN tests were used to test for significant differences (at a significant level of 0.05) using SPSS 16.0.

\section{RESULTS}

\subsection{Water quality parameters of the experiment}

The environmental parameters such as temperature, $\mathrm{DO}, \mathrm{pH}, \mathrm{NO}_{2}^{-}$, and TAN were showed in Table 1. The DO, temperature, and $\mathrm{pH}$ had slight variation among the treatments. However, $\mathrm{NO}_{2}{ }^{-}$ranged from 0.10 to $0.20 \mathrm{mg} / \mathrm{L}$ and $\mathrm{TAN}$ ranged from 0.07 to $0.40 \mathrm{mg} / \mathrm{L}$, which increased in the higher salinity if compared to the control treatment ( freshwater treatment). All water quality parameters were within suitable ranges for fish growth (Boyd, 1998).

Table 1. Water quality parameters of experimental tanks during the experiment

\begin{tabular}{lrrrrrr}
\hline Treatment & $\mathbf{0 \%}$ & $\mathbf{3 \%}$ & $\mathbf{6 \%}$ & $\mathbf{9 \%}$ & $\mathbf{1 2 \%}$ & $\mathbf{1 5 \%}$ \\
\hline $\mathrm{pH}$ & $7.59 \pm 0.11$ & $7.60 \pm 0.025$ & $7.53 \pm 0.08$ & $7.51 \pm 0.11$ & $7.66 \pm 0.06$ & $7.64 \pm 0.02$ \\
$\mathrm{Temp}\left({ }^{\circ} \mathrm{C}\right)$ & $27.6 \pm 0.025$ & $27.55 \pm 0.04$ & $27.55 \pm 0.03$ & $27.55 \pm 0.01$ & $27.7 \pm 0.12$ & $27.6 \pm 0.05$ \\
$\mathrm{Oxy}(\mathrm{mg} / \mathrm{L})$ & $5.08 \pm 0.04$ & $5.39 \pm 0.05$ & $5.26 \pm 0.09$ & $5.49 \pm 0.09$ & $5.49 \pm 0.06$ & $5.34 \pm 0.22$ \\
$\mathrm{NO}_{2}{ }^{-}(\mathrm{mg} / \mathrm{L})$ & $0.10 \pm 0.03$ & $0.17 \pm 0.03$ & $0.19 \pm 0.02$ & $0.20 \pm 0.02$ & $0.14 \pm 0.03$ & $0.16 \pm 0.02$ \\
$\mathrm{TAN}(\mathrm{mg} / \mathrm{L})$ & $0.07 \pm 0.05$ & $0.27 \pm 0.08$ & $0.39 \pm 0.05$ & $0.40 \pm 0.01$ & $0.16 \pm 0.11$ & $0.16 \pm 0.02$ \\
\hline
\end{tabular}

Note: The values shown in the table were mean $\pm S D$.

\subsection{Growth performance}

All growth parameters showed the same pattern after 60 experimental days (Table 2). The growth performance was insignificantly different in the salinities from 0 to $12 \%$ o $(p>0.05)$, in which the fish in
$9 \%$ had the best growth. The fish in $15 \%$ had significantly low in growth compared to that of other treatments $(\mathrm{p}<0.05)$. The weight and length of fish in $9 \%$ and $15 \%$ was $5.57 \pm 1.60 \mathrm{~g} ; 8.43 \pm 0.67 \mathrm{~cm}$ and $1.52 \pm 0.49 \mathrm{~g} ; \quad 6.00 \pm 0.30 \mathrm{~cm}$, respectively. 
Particularly, the biggest and smallest SGR were found in the treatments with $9 \%$ and $15 \%$ with
$14.3 \pm 0.45$ and $12.2 \pm 0.60 \% /$ day, respectively $(\mathrm{p}<0.05)$.

Table 2. Growth performance of fish after 60 days of culture in different salinities

\begin{tabular}{lrrrrrr}
\hline \multirow{2}{*}{ Parameter } & \multicolumn{7}{c}{ Treatment/salinity (\%o) } \\
\cline { 2 - 7 } & $\mathbf{0}$ & $\mathbf{3}$ & $\mathbf{6}$ & $\mathbf{9}$ & $\mathbf{1 2}$ & $\mathbf{1 5}$ \\
\hline Initial weight (g) & 0.001 & 0.001 & 0.001 & 0.001 & 0.001 & 0.001 \\
Final weight (g) & $5.02 \pm 0.10^{\mathrm{b}}$ & $5.08 \pm 1.4^{\mathrm{b}}$ & $4.97 \pm 0.25^{\mathrm{b}}$ & $5.57 \pm 1.60^{\mathrm{b}}$ & $4.13 \pm 0.46^{\mathrm{b}}$ & $1.52 \pm 0.49^{\mathrm{a}}$ \\
Final Length (cm) & $8.23 \pm 0.25^{\mathrm{b}}$ & $8.16 \pm 1.45^{\mathrm{b}}$ & $8.30 \pm 0.46^{\mathrm{b}}$ & $8.43 \pm 0.67^{\mathrm{b}}$ & $7.90 \pm 0.50^{\mathrm{b}}$ & $6.00 \pm 0.30^{\mathrm{a}}$ \\
DWG (g/day) & $0.08 \pm 0.02^{\mathrm{b}}$ & $0.08 \pm 0.03^{\mathrm{b}}$ & $0.08 \pm 0.01^{\mathrm{b}}$ & $0.09 \pm 0.03^{\mathrm{b}}$ & $0.07 \pm 0.01^{\mathrm{b}}$ & $0.03 \pm 0.01^{\mathrm{a}}$ \\
SGR (\%/day) & $14.2 \pm 0.04^{\mathrm{b}}$ & $14.2 \pm 0.47^{\mathrm{b}}$ & $14.2 \pm 0.09^{\mathrm{b}}$ & $14.3 \pm 0.45^{\mathrm{b}}$ & $13.9 \pm 0.19^{\mathrm{b}}$ & $12.2 \pm 0.60^{\mathrm{a}}$ \\
DLG (cm/day) & $0.13 \pm 0.01^{\mathrm{b}}$ & $0.13 \pm 0.03^{\mathrm{b}}$ & $0.13 \pm 0.01^{\mathrm{b}}$ & $0.14 \pm 0.01^{\mathrm{b}}$ & $0.13 \pm 0.01^{\mathrm{b}}$ & $0.09 \pm 0.01^{\mathrm{a}}$ \\
\hline
\end{tabular}

Data shown in mean $\pm S D$. Values with the same lowercase letter $(a, b)$ in the same row were not significantly different $(p>0.05)$.

\subsection{Survival rate}

The lowest survival rate was recorded in treatment with $15 \% 0(1.25 \%)$ and was significantly different from the other treatments $(\mathrm{p}<0.05)$. In the high salinity treatments, fish mortality was mostly found during the first 2 weeks of the experiment, especially in $15 \%$ o treatment. The survival rate in $6 \%$ treatment was highest with a value of $60.6 \%$ and statistically significant compared to the treatments of $9 \%$ (30.9\%), 12\%o (8.33\%) and 15\% (1.25\%).

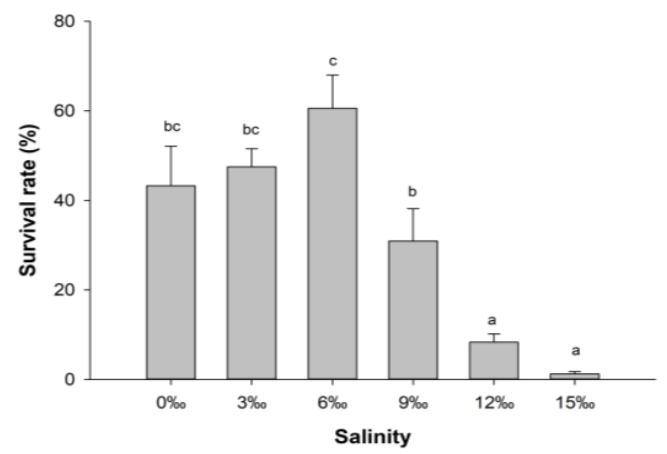

Fig. 1. Survival rate of striped catfish after 60 days of culture at different salinities

Data shown in mean $\pm S D$. Values with the same lowercase letter $(a, b, c)$ in figure were not significantly different $(p>0.05)$.

Table 4. Number of red blood cells $\left(10^{6}\right.$ cells $\left./ \mathrm{mm}^{3}\right)$, white blood cells $\left(10^{3} \mathrm{cells} / \mathrm{mm}^{3}\right)$, hemoglobin concentration $(\mathrm{g} / 100 \mathrm{~mL})$, and hematocrit $(\%)$ in the blood of striped catfish in different salinities

\begin{tabular}{lrrrrr}
\multicolumn{5}{c}{ centration $(\mathbf{g} / \mathbf{1 0 0} \mathbf{~} \mathbf{L})$, and hematocrit $\mathbf{( \% )}$ in the blood of striped catfish in different salinities } \\
\cline { 2 - 6 } Parameter & \multicolumn{5}{c}{ Treatment/salinity (\%) } \\
\cline { 2 - 6 } & \multicolumn{6}{c}{$\mathbf{0}$} & $\mathbf{3}$ & $\mathbf{6}$ & $\mathbf{9}$ & $\mathbf{1 2}$ \\
\hline RBCs & $2.54 \pm 0.38^{\mathrm{a}}$ & $2.57 \pm 0.13^{\mathrm{a}}$ & $2.71 \pm 0.12^{\mathrm{a}}$ & $2.48 \pm 0.47^{\mathrm{a}}$ & $2.18 \pm 0.18^{\mathrm{a}}$ \\
WBCs & $85.3 \pm 6.66^{\mathrm{a}}$ & $100 \pm 10.7^{\mathrm{a}}$ & $111 \pm 16.6^{\mathrm{a}}$ & $86.3 \pm 13.0^{\mathrm{a}}$ & $119 \pm 34.0^{\mathrm{a}}$ \\
Hemoglobin & $9.52 \pm 1.4^{\mathrm{ab}}$ & $10.92 \pm 1.36^{\mathrm{abc}}$ & $12.1 \pm 0.71^{\mathrm{c}}$ & $11.3 \pm 0.39^{\mathrm{bc}}$ & $9.11 \pm 0.56^{\mathrm{a}}$ \\
Hematocrit & $42.3 \pm 3.37^{\mathrm{a}}$ & $48.9 \pm 6.24^{\mathrm{a}}$ & $41.6 \pm 5.88^{\mathrm{a}}$ & $43.0 \pm 2.57^{\mathrm{a}}$ & $41.0 \pm 1.19^{\mathrm{a}}$ \\
\hline
\end{tabular}

Data shown in mean $\pm S D$. Values with the same lowercase letter $(a, b, c)$ in the same row were not significantly different $(p>0.05)$.

\subsection{Physiological parameters}

The low survival rate $(1.25 \%)$ and small fish weight $(1.52 \pm 0.49 \mathrm{~g})$ in $15 \%$ o treatment did not meet the requirements for physiological parameter sampling. Therefore, fish of 4 salinity treatments from 0 to $12 \%$ were sampled for physiological responses.

\subsubsection{Red blood cells, white blood cells, hemoglobin $(\mathrm{Hb})$ and hematocrit (Hct)}

The results observed showed that the hematological parameters such as RBCs, WBCs, hematocrit were not affected by salinity (Table 4). RBCs ranged from $2.18 \pm 0.18$ to $2.71 \pm 0.12\left(\times 10^{6}\right.$ cells $\left./ \mathrm{mm}^{3}\right)$; white blood cells fluctuated from $85.3 \pm 6.66$ to $119 \pm 34.0$ $\left(\times 10^{3}\right.$ cells $\left./ \mathrm{mm}^{3}\right)$ and hematocrit were obtained from $41.0 \pm 1.19$ to $48.9 \pm 6.24 \%$. These indicators tend to increase with the increased salinity but decrease at $12 \%$ treatment. However, the highest $\mathrm{Hb}$ concentration was recorded in treatment 6\% $(12.1 \pm 0.71 \mathrm{~g} / 100 \mathrm{~mL})$, but insignificantly different compared to $9 \%$ treatment $(11.30 \pm 0.39 \mathrm{~g} / 100 \mathrm{~mL})$ and $3 \%$ treatment $(10.92 \pm 1.36 \mathrm{~g} / 100 \mathrm{~mL})(\mathrm{p}>0.05)$. The lowest $\mathrm{Hb}$ concentration was in treatment $12 \%$ $(9.11 \pm 0.56 \mathrm{~g} / 100 \mathrm{~mL})$, which was significantly different from $6 \%$ and $9 \%$ treatments $(p<0.05)$. Generally, the $\mathrm{Hb}$ concentration increased with elevated salinities but decreased in the condition above $12 \%$. 


\subsubsection{Glucose and cortisol concentration}

The concentrations of glucose and cortisol increased with elevated salinities. These parameters indicated that the experimentally increased salinities elevated the stress in striped catfish. The glucose concentration increased in the high salinity treatment of $12 \%$
$(97.0 \pm 3.50 \mathrm{mg} / 100 \mathrm{~mL})$, while lowest in the $0 \%$ (control) treatment $(80.2 \pm 8.46 \mathrm{mg} / 100 \mathrm{~mL})$ (Table 5). Similarly, cortisol concentrations increased but no significant difference was found among the treatments. The highest cortisol concentration was in $12 \%$ treatment $(105 \pm 24.0 \mathrm{ng} / \mathrm{mL})$ and lowest was in the $0 \%$ treatment $(84.1 \pm 14.1 \mathrm{ng} / \mathrm{mL})$.

Table 5. Glucose and cortisol concentration in plasma under salinity effects

\begin{tabular}{lrrrrr}
\hline \multirow{2}{*}{ Parameter } & \multicolumn{5}{c}{ Treatment/salinity (\%o) } \\
\cline { 2 - 6 } & $\mathbf{0}$ & $\mathbf{3}$ & $\mathbf{6}$ & $\mathbf{9}$ & $\mathbf{1 2}$ \\
\hline Glucose $(\mathrm{mg} / 100 \mathrm{~mL})$ & $80.2 \pm 8.46^{\mathrm{a}}$ & $81.3 \pm 11.36^{\mathrm{a}}$ & $81.8 \pm 10.3^{\mathrm{a}}$ & $88.6 \pm 9.76^{\mathrm{a}}$ & $97.0 \pm 3.50^{\mathrm{a}}$ \\
Cortisol $(\mathrm{ng} / \mathrm{mL})$ & $84.1 \pm 14.1^{\mathrm{a}}$ & $88.2 \pm 8.83^{\mathrm{a}}$ & $93.0 \pm 10.2^{\mathrm{a}}$ & $93.0 \pm 8.77^{\mathrm{a}}$ & $105 \pm 24.0^{\mathrm{a}}$ \\
\hline
\end{tabular}

Data was shown in mean $\pm S D$. Values with the same lowercase letter in the same row were not significantly different $(p>0.05)$.

\subsubsection{Osmolality, ion $\mathrm{Na}+\mathrm{K}+$ and $\mathrm{Cl}$ -}

The plasma osmolality and concentration of $\mathrm{Na}^{+}$; $\mathrm{K}^{+} ; \mathrm{Cl}^{-}$of experimental fish were influenced at high salinities (Table 6). The plasma osmolality increased from the control treatment $(273 \pm 2.52$ $\mathrm{mOsm} / \mathrm{kg})$ to the $12 \%$ treatment $(289 \pm 1.00$ $\mathrm{mOsm} / \mathrm{kg}$ ). The osmolalities at treatment $9 \%$ and $12 \%$ were significantly higher than that in the other treatment $(\mathrm{p}<0.05)$. The $\mathrm{Na}^{+}, \mathrm{K}^{+}$, and $\mathrm{Cl}^{-}$concentrations in fish plasma increased with salinity from $0 \%$

Table 6. Osmolarity $(\mathrm{mOsm} / \mathrm{kg})$ and $\mathrm{Na}^{+} ; \mathrm{K}^{+} ; \mathrm{Cl}^{-}$concentrations $(\mathrm{mM})$ of fish reared in different salinities

\begin{tabular}{lrrrrr}
\hline \multirow{2}{*}{ Parameter } & \multicolumn{5}{c}{ Treatment/salinity (\%o) } \\
\cline { 2 - 6 } & $\mathbf{0}$ & $\mathbf{3}$ & $\mathbf{6}$ & $\mathbf{9}$ & $\mathbf{1 2}$ \\
\hline Osmolality & $273 \pm 2.52^{\mathrm{a}}$ & $274 \pm 3.46^{\mathrm{a}}$ & $276 \pm 4.35^{\mathrm{a}}$ & $286 \pm 1.15^{\mathrm{b}}$ & $289 \pm 1.00^{\mathrm{b}}$ \\
${\text { Ion } \mathrm{Na}^{+}}^{\text {Ion } \mathrm{K}^{+}}$ & $107 \pm 2.35^{\mathrm{a}}$ & $122 \pm 11^{\mathrm{ab}}$ & $130 \pm 16.2^{\mathrm{b}}$ & $136 \pm 4.01^{\mathrm{b}}$ & $160 \pm 6.99^{\mathrm{c}}$ \\
${\text { Ion } \mathrm{Cl}^{-}}^{\mathrm{a}}$ & $8.50 \pm 0.25^{\mathrm{a}}$ & $9.40 \pm 0.50^{\mathrm{a}}$ & $11.5 \pm 1.22^{\mathrm{b}}$ & $12.7 \pm 0.53^{\mathrm{bc}}$ & $13.7 \pm 0.72^{\mathrm{c}}$ \\
\hline
\end{tabular}

Data shown in mean $\pm S D$. Values with the same lowercase letter $(a, b, c)$ in the same row were not significantly different $(p>0.05)$.

\subsubsection{Digestive enzyme activities}

The highest chymotrypsin activity was found in the treatment with $0 \%$ o $(122 \pm 6.04 \mathrm{U} / \mathrm{min} / \mathrm{mg}$ protein $)$ and significantly different from the $9 \%, 12 \%$ and $15 \%$ treatments. By contrast, the lowest result was recorded at $15 \%$ o $(69.2 \pm 2.46 \mathrm{U} / \mathrm{min} / \mathrm{mg}$ protein $)$ and was statistically different from the other treatments, except the $12 \%$ treatment. The highest trypsin activity was found at the salinity level of $3 \%$ to $12 \%$. $\mathrm{Na}^{+}$concentration increased from $107 \mathrm{mM}$ to $160 \mathrm{mM}$. The highest concentration of $\mathrm{K}^{+}$ion was in the fish exposed to $12 \%$ o $(13.7 \pm 0.72 \mathrm{mM})$, and the lowest was in the fish in the control treatment $0 \%$ $(8.50 \pm 0.25 \mathrm{mM})$. Similarly, $\mathrm{Cl}^{-}$concentration increased from $101 \pm 7.47 \mathrm{mM}$ to $119 \pm 3.12 \mathrm{mM}$. The concentration of $\mathrm{Na}^{+}, \mathrm{K}^{+}$ions at treatment $6 \%$ was significantly higher than that in the control, but the $\mathrm{Cl}^{-}$concentration was only significantly different from the control and $12 \%$ treatment. 
Table 7. Digestive enzymes in the intestines and stomach of catfish under salinity effects

\begin{tabular}{|c|c|c|c|c|c|c|}
\hline \multirow{2}{*}{ Parameter } & \multicolumn{6}{|c|}{ Treatment/salinity (\%o) } \\
\hline & 0 & 3 & 6 & 9 & 12 & 15 \\
\hline $\begin{array}{l}\text { otrypsin }(\mathrm{U} / \mathrm{min} / \mathrm{mg} \\
\mathrm{n})\end{array}$ & $122 \pm 6.04^{\mathrm{c}}$ & $112 \pm 5.03^{\mathrm{c}}$ & $108 \pm 12.8^{\mathrm{bc}}$ & $95.7 \pm 3.69^{\mathrm{b}}$ & $78.4 \pm 10.6^{\mathrm{a}}$ & $69.2 \pm 2.46^{\mathrm{a}}$ \\
\hline $\begin{array}{l}\text { Trypsin } \\
\text { (mU/min/mg protein }\end{array}$ & $2.69 \pm 0.31^{\mathrm{ab}}$ & $2.90 \pm 0.73^{\mathrm{b}}$ & $2.47 \pm 1.11^{\mathrm{ab}}$ & $1.95 \pm 0.53^{\mathrm{ab}}$ & $1.94 \pm 0.65^{\mathrm{ab}}$ & $1.46 \pm 0.01^{\mathrm{a}}$ \\
\hline $\begin{array}{l}\text { Amylase } \\
\text { (U/min/mg protein) }\end{array}$ & $3.10 \pm 0.50^{\mathrm{a}}$ & $3.26 \pm 0.52^{\mathrm{a}}$ & $3.22 \pm 0.30^{\mathrm{a}}$ & $3.49 \pm 0.43^{\mathrm{a}}$ & $3.52 \pm 0.43^{\mathrm{a}}$ & $4.55 \pm 0.81^{\mathrm{a}}$ \\
\hline $\begin{array}{l}\text { Pepsin } \\
\text { (U/min/mg protein) }\end{array}$ & $0.61 \pm 0.08^{\mathrm{a}}$ & $0.49 \pm 0.03^{\mathrm{a}}$ & $0.40 \pm 0.08^{\mathrm{a}}$ & $0.45 \pm 0.22^{\mathrm{a}}$ & $0.62 \pm 0.21^{\mathrm{a}}$ & $0.44 \pm 0.07^{\mathrm{a}}$ \\
\hline
\end{tabular}

Data shown in mean $\pm S D$. Values with the same lowercase letter $(a, b, c)$ in the same row were not significantly different $(p>0.05)$.

\section{DISCUSSION}

\subsection{Growth performance}

Previous studies (Lam et al., 2011; Thao et al., 2013; Hoa 2014) showed that the striped catfish at the juvenile stage subjected to $9-10 \%$ o had the highest weight in comparison with that in higher or lower salinities. Nahar et al. (2016) reported that SGR in fingerling climbing perch (Anabas testudineus) decreased with the increase of salinitiy in the range of 0 to $15 \%$ after 60 days rearing. In addition, larvae snakehead (Channa striata) showed high growth rate at 0 and $3 \%$ after 90 days rearing (Huong et al., 2020). It is clear that each species has the best growth at specific salinity levels, and the present study proved that the level of $9 \%$ is the optimal condition for growth performance in striped catfish at larvae to fry stages. This can be explained by the fact that $9 \%$ is the iso-osmotic point of the striped catfish (Huong \& Quyen, 2012; Phuc et al., 2014), so the fish utilizes less energy for regulating osmotic pressure and other metabolic processes leading to the optimal growth performance of fish.

\subsection{Survival rate}

Fish feeding was gradually changed from live feed to commercial pellet (during larvae stage) and this might have led to scattered mortality in all treatments. In addition, although striped catfish is the freshwater species but the survival rate in freshwater environment $(43.3 \%)$ was lower than the survival rate in the environment with $6 \% 0(60.6 \%)$ and $3 \% 0$ $(47.5 \%)$. Quyen (2011) reported that the striped catfish at larvae stage cultured in different salinities $(0$, $1,3,5,7$ and $9 \%$ ) in 60 days had the highest survival rates in $1 \%$ treatment $(46.2 \%)$, which was similar to the present study's results $(43.3 \%)$, but the lowest survival rate was in $9 \%$ treatment $(17.8 \%)$, which was much lower compared to the findings of this study (30.9\%). In the present study, fish of the high salinity $(9,12$ and $15 \%)$ treatments showed low appetite during experiment and this caused in high motality rate. This similar to A. testudineus fingerling, showed high appetite towards food between 0 and $6 \%$ with survival rate of $100 \%$. While at salinities $12 \%, 15 \%$ o the fish showed moderate and low appetite with survival rate of $60 \%$ and $20 \%$, respectively (Nahar et al., 2016).

\subsection{Physiological parameters}

The increases of hematocrit concentrations were related to the loss of a high quantity of water because of the difference between the internal and external environmental ions concentrations, while the increase of RBC may result from the increase of oxygen consumption owing to the increase of energy requirement (Al-Hilali \& Al-Khshali, 2016). The increase of RBC caused elevated of $\mathrm{Hb}$ concentartion at salinities lower 9\%. These changes can be also explained by changes in the water content in blood when the fish exposed to a hyperosmotic environment. The fish would be lose water passively at the beginning of expose, that resulted increase in the concentration of blood-cell elements (Martínez-Álvarez et al., 2002). However, the salinity exceeding $9 \%$ caused the decreased trend of RBCs, and hematocrit concentrations due to the increase of osmolality can reduce the volume of RBCs, and thus Hct values also decrease (Hosseini et al., 2011). Besides, at the salinity of $9 \%$, relatively estimated as iso-osmotic point in striped catfish (Huong \& Quyen, 2012), the internal and external osmolality was in equilibrium. Therefore, metabolic activities and physiological parameters gradually stabilized (Smith, 1982; Evans, 1993). In current study, the $\mathrm{RBCs}, \mathrm{Hb}$ and hematocrit concentrations slightly decreased at salinity higher $9 \%$. Similarly, the study of Huong et al. (2020) on striped snakehead showed 
that these indicators gradually decreased with increase of salinity.

Generally, stress increases plasma glucose that provides energy for animals to respond to stress. Due to the acclimation time of 60 days, the fish gradually stabilized and accustomed to the salinity environment. Therefore, the glucose concentration among treatments was not significantly different. Martínez-Porchas et al. (2009) suggested that there are some cases that the plasma glucose content only slightly increased or unchanged under shocked or stressed effects. In the study on effect of salinity on fingerling striped catfish, it was found that six different salinity levels $(0,2,6,10,14,18 \%)$ affecting striped catfish. The glucose concentration increased with an increase in salinity, the highest values were found after 6 hours in treatments of 14 and 18\%o ( 90.4 and $102 \mathrm{mg} / 100 \mathrm{~mL}$ ). Besides, the cortisol concentration was highest in the treatments of $18 \%$ $(28,505 \mathrm{pg} / \mathrm{mL})$, which was significantly different from the treatment of control (Thao, 2013). However, the author also found that the plasma glucose and cortisol levels in all treatments started to decrease at 4 days of experiment and there was an insignificant difference among treatments after 14 days (Thao, 2013).

The plasma osmolality found from the present study was in line with the results reported by Huong et al. (2008) that the iso-osmotic point in striped catfish fingerling size was at $9 \%$ ( $270 \mathrm{mOsm} / \mathrm{kg})$. In addition, Huong and Quyen (2012) study on striped catfish from larvae to juvenile stages showed that the plasma osmolality increased from 0-11\% (225-302 $\mathrm{mOsm} / \mathrm{kg}$ ) and iso-osmotic point in larvae was also at $9 \%$ o $(297 \mathrm{mOsm} / \mathrm{kg})$. Each fish had its tolerance to salinity and the optimum range for its development; and the ability to tolerate the salinity of fish depends on the method of acclimation. In the experiment, the salinity was increased by $1 \%$ per 8 hours, this could have enough time for fish to adapt to the increased salinity, therefore the plasma osmolality in $12 \%$ o treatment $(289 \pm 1 \mathrm{mOsm} / \mathrm{kg})$ was significantly different $(\mathrm{p}<0.05)$ from that of 0,3 and $6 \%$ salinity treatments, but insignificantly different from that of $9 \%$ treatment $(286 \pm 1.15 \mathrm{mOsm} / \mathrm{kg})$. Being a freshwater species, striped catfish transferred into brackish water must constantly discharge salt and keep a certain amount of water to maintain the internal environment. Most of the food-based water entering the digestive tract was absorbed into the bloodstream. Only water-soluble ions with a valency of $1\left(\mathrm{as} \mathrm{Na}^{+} ; \mathrm{K}^{+}\right.$, and $\left.\mathrm{Cl}^{-}\right)$were absorbed, while most ions with a valency of $2\left(\mathrm{Ca}^{2+}\right.$ and $\left.\mathrm{Mg}^{2+}\right)$ were excreted through feces with a few of them being absorbed (Tuan, 1981). Another research on striped catfish showed that the concentration of $\mathrm{Na}^{+}$in the plasma increased from $71 \mathrm{mM}$ to $163 \mathrm{mM}$ with an increase of salinity from $0 \%$ to $23 \%$; and $\mathrm{Na}^{+}$isoosmotic point of larvae stage was about $9 \%$ o $(97 \pm 7$ $\mathrm{mM}$ ) (Quyen, 2011). It is clear that salinity increases the concentration of $\mathrm{Na}^{+}, \mathrm{K}^{+}$, and $\mathrm{Cl}^{-}$. This was supported by Lam et al. (2010) that $\mathrm{Na}^{+}, \mathrm{K}^{+}$, and $\mathrm{Cl}^{-}$ concentrations gradually increased in fish subjected from 0 to $15 \%$ with concentrations of $135-197 \mathrm{mM}$, 8.4-8.7 mM, and 106-116 mM, respectively. Besides, hybrid yellow catfish cultured in different salinities from 0 to $18 \%$ gradually elevated osmolality, $\mathrm{Na}^{+}$, and $\mathrm{Cl}^{-}$(Nam \& Huong, 2011).

\subsection{Enzymatic activities}

The effect of salinity changes on digestive enzymatic activities in the experiment showed that salinity caused an increase of enzyme activities and may also inhibit enzymatic activities if it exceeds the appropriate salinity ranges of species (Chen,1998; Yin et al., 2010). Environmental salinity may affect the enzymatic activities in teleost fish. This could be explained by the changes in $\mathrm{pH}$ and ion strength in the digestive tract through water ingestion or excretion during osmoregulation activity. Besides, it may relate to homeostasis maintainability, requiring higher food intake and then increased enzymatic activity (Barman et al., 2005; Bœuf and Payan, 2001; Pujante et al., 2018; Usher et al., 1990). When the freshwater species transferred in to brackish water, the fish must constantly excrete salt (ion $\mathrm{Na}^{+}, \mathrm{Cl}^{-}$) and keep a certain amount of water to maintain the stable osmolality. The movement electrolyte ion can be accomplished by facilitated diffusion and active transport. Active transport requires energy in the form of ATP conversion (Molnar \& Gair, 2013). However, at the iso-osmotic point, fish consume less energy for regulating the osmotic pressure and other activities (Lisboa et al., 2015). Hoa (2014) reported that enzymatic activities in striped catfish increased with elevated salinities 0,3 and $6 \%$, and reached the highest value in $9 \%$ treatment, but decreased at 12 and $15 \%$ o treatments after 56 days. Similarly, the activity of amylase in snakehead fish (Channa striata) tended to increase in treatments of 3, 6 and 9\%, followed by the decrease of activities at 12 and $15 \%$. It was demonstrated that high salinity affected the amylase activity in the fish intestine (Tinh, 2013). In the present study, high salinity resulted in the decrease of trypsin and chymotrypsin activities as well as the appetite and digestion of the 
fish. Those reasons lead to a decreased in growth and survival rate on striped catfish.

\section{CONCLUSIONS}

Striped catfish larvae grew well in a range of salinity from 0 to $9 \%$. The survival rate of fish was the highest at $6 \%$. Digestive enzyme activities and plasma osmolality were not affected in the salinity at $6 \%$. It is sugguested that the optimal salinity for striped catfish larvae rearing was in the range of from 0 to $6 \%$.

\section{ACKNOWLEDGMENT}

This study was funded in part by the Can Tho University Improvement Project VN14-P6 supported by a Japanese ODA loan.

\section{REFERENCES}

Abdel-Tawwab, M., Mousa, M. A., Sharaf, S. M. \& Ahmad, M. H. (2005). Effect of crowding stress on some physiological functions of Nile tilapia, Oreochromis niloticus (L.) fed different dietary protein levels. International Journal of Zoological Research, 1(1), 41-47.

Al-Hilali, H. A. \& Al-Khshali, M. S. (2016). Effect of water salinity on some blood parameters of common carp (Cyprinus carpio). International Journal of Applied Agricultural Sciences, 2(1), 17-20.

Ane, A., Taher, T., Islam, S. M. M., Uddin, H., Islam, M., \& Shahjahan, M. (2019). Striped catfish (Pangasianodon hypophthalmus) could be suitable for coastal aquaculture. Journal of Applied Ichthyology, 35(4), 994-1003.

Barman, U.K., Jana, S.N., Garg, S.K., Bhatnagar, A., \& Arasu, A.R.T. (2005). Effect of inland water salinity on growth, feed conversion efficiency, and intestinal enzyme activity in growing grey mullet, Mugil cephalus (Linn.): Field and laboratory studies. Aquaculture International: Journal of the European Aquaculture Society, 13(3), 241-256 Doi: 10.1007/s10499-004-2479-5.

Bernfeld, P. (1951). Enzymes of starch degradation and synthesis. In. F. F. Nord (Eds.), Advances in enzymology and related areas of molecular biology (pp. 379-428). Interscience Publishers, Inc. Doi: 10.1002/9780470122570.ch7.

Bœuf, G., and Payan, P. (2001). How should salinity influence fish growth? Comparative Biochemistry and Physiology Part C: Toxicology \& Pharmacology, 130, 411-423.

Boyd, C. E. (1998). Water quality for ponds Aquaculture. Research and Development series No.43, August 1998, Alabama, 37 pp.

Chen, P. (1998). Effects of salinity on digestive enzyme activity of Pagrosomus major young fish. Journal-
Xiamen University Natural Science, 37, 756-761. (English Abstract).

Evans, D. H. (1993). Osmotic and Ionic Regulation. In D. H. Evans (Eds.), The Physiology of Fishes (pp. 315-341). CRC Press, Boca Raton.

Giang, T.T. (2008). Effects of salinity on physiological respond and growth performance of mudskipper (Pseudapocryptes lanceolatus, Bloch 1801) (master's thesis). Can Tho University, Can Tho city, Vietnam (in Vietnamese).

Hamed, S. S., Jiddawi, N. S., \& Poj, B. (2016). Effect of salinity levels on growth, feed utilization, body composition, and digestive enzymes activities of juvenile silver pompano Trachinotus blochii. International Journal of Fisheries and Aquatic Studies, 4, 279-283.

Hoa, H. T. (2014). Effects of salinity on digestive enzyme activities of striped catfish (Pangasianodon hypophthalmus) (master's thesis). Can Tho University, Can Tho city, Vietnam (in Vietnamese).

Hosseini, P., Vahabzadeh Roodsari, H., Sayyad Bourani, M., \& Kazemi, R. (2011). The effect of salinity stress on hematocrite and hemoglobin in fingerling Rainbow trout (Onchorhynchus mykiss). International Conference on Medical, Biological and Pharmaceutical Sciences, (ICMBPS'2011) Pattaya.

Hugget, A. S. G. and Nixon, D. A. (1957). Use of glucose oxidase, peroxidase and o-dianisidine in determination of blood and urinary glucose. The Lancet, 270(6991), 368-370. doi: 10.1016/s01406736(57)92595-3

Huong, D. T .T., Ky, T. M., Ha, N. T. K., Em, N. T., Takagi Y. \& Phuong, N. T. (2020). Effects of salinity on physiological parameters, digestive enzyme activities, and growth of snakehead fish (Channa striata). Can Tho University Journal of Science. Special issue on Aquaculture and Fisheries, 56(1), 1119. (in Vietnamese).

Huong, D. T. T. \& Quyen, T. N. T. (2012). The effect of salinity on the embryonic development and osmoregulatory of the striped catfish (Pangasianodon hypophthalmus) larvae and fingerling stages. Can Tho University Journal of Science, 21b, 29-37 (in Vietnamese).

Huong, D. T. T. \& Tu, N. V. (2010). Introduction to the physiology and fish and crustacean. Agricultural publishing house. Ho Chi Minh city (in Vietnamese)

Huong, D. T. T., Phuong, N. T., Wang, T., Thuy, N. H., \& Bayley, M. (2008). Osmotic ang ionic regulation, food intake and growth of striped catfish (Pangasianodon hypophthalmus) exposed to different salinities. Handbook and abstract of the international symposium on catfish aquaculture in Asia: Present status and challenge for suitable development. Can Tho University. 5-6 $6^{\text {th }}$ December 2008. p.65.

Lam, N. C., Huong, D. T. T., Son, V. N., \& Phuong, N. T. (2011). Physiological changes and growth of tra catfish (Pangasianodon hypophthalmus) exposed to 
different salinities. Can Tho University Journal of Science, 17a, 60-69. (in Vietnamese).

Lisboa, V., Barcarolli, I.F., Sampaio, L.A. \& Bianchini, A. (2015). Effect of salinity on survival, growth and biochemical parameters in juvenile Lebranch mullet Mugil liza (Perciformes: Mugilidae). Neotropical Ichthyology, 13(2), 447-452.

Martinez-Alvarez, R.M., Hidalgo, M.C., Domezain, A., Morales, A.E., García-Gallego, M. \& Sanz, A. (2002). Physiological changes of sturgeon Acipenser naccarii caused by increasing environmental salinity. Journal of experimental biology, 205(23), 3699-3706.

Martínez-Porchas, M., Martínez-Córdova, L.R. \& Ramos-Enríquez, R. (2009). Cortisol and glucose: Reliable indicators of fish stress?. Pan-American Journal of Aquatic Sciences, 4, 158-178.

Molnar, C. \& Gair, J. (2013). Osmoregulation and Osmotic Balance. Concepts of Biology-1 st Canadian Edition.

MoNRE (Ministry of Natural Resources and Environment) (2016). Climate change and sea-level rise scenarios for Vietnam: Summary for policymakers.

Nahar, F., Haque, W., Ahsan, D.A., \& Mustafa, M. D. G. (2015). Effects of salinity changes on growth performance and survival of Climbing perch, Anabas testudineus (Bloch, 1795). Dhaka University Journal of Biological Science, 25(1), 65-73.

Nam, P.T. \& Huong, D.T.T. (2011). The osmoregulation and growth of hybrid yellow catfish juvenile (Clarias macrocephalus Gunther $x$ Clarias gariepinus) exposed to the different salinities. Can Tho University Journal of Science, 20b, 39-47 (in Vietnamese).

Nguyen, A.L., Dang, V.H., Bosma, R.H., Verreth, J.A., Leemans, R. \& De Silva, S.S. (2014). Simulated impacts of climate change on current farming locations of striped catfish (Pangasianodon hypophthalmus; Sauvage) in the Mekong Delta, Vietnam. Ambio. 43(8), 1059-1068.

Oser, B.L., (1965). Blood analysis. Hawk's physiological chemistry. p.1096.

Phuc, N. T. H., Huong, D. T. T., Mather, P. B., \& Hurwood, D. A. (2014). Experimental assessment of the effects of sublethal salinities on growth performance and stress in 126 cultured tra catfish (Pangasianodon hypophthalmus). Fish Physiology and Biochemistry, 40, 1839-1848.

Pujante, I. M., Moyano, F. J., Martos-Sitcha, J. A., Mancera, J. M., \& Martinez-Rodriguez, G. (2018). Effect of different salinities on gene expression and activity of digestive enzymes in the thick-lipped grey mullet (Chelon labrosus). Fish Physiological and Biochemistry, 44, 349-373.

Quyen, T. N. T. (2011). The effect of salinity on embryo development and osmoregulation of striped catfish (Pangasianodon hypophthalmus) (master's thesis). Can Tho University, Can Tho city, Vietnam (in Vietnamese).

Smith, S. L. (1982). Introduction to Fish Physiology. T. F. H. Publications, Inc.

Thao, N. L. (2013). Effect of salinity on growth performance and stress of striped catfish (Pangasianodon hypophthalmus). Master's thesis. Can Tho University, Can Tho city, Vietnam (in Vietnamese).

Tinh, N. T. (2013). Effects of salinity on digestive enzyme activities and growth performance of striped snakehead (Channa striata) (master's thesis). Can Tho University, Can Tho city, Vietnam (in Vietnamese).

Tseng, H. C., Grendell, J. H. \& Rothman, S. S. (1982). Food, duodenal extracts, and enzyme secretion by the pancrease. American Journal of Physiology, 243, 304-312.

Tsuzuki, M. Y., Sugai, J. K., Maciel, J. C., Francisco, C. J., \& Cerqueira, V. R. (2007). Survival, growth and digestive enzyme activity of juveniles of the fat snook (Centropomus parallelus) reared at different salinities. Aquaculture, 271, 319-325.

Tuan, D. (1981). Fish physiology. Hanoi Agricultural Publishing House (in Vietnamese).

Usher, M. L., Talbot, C., \& Eddy, F. B. (1990). Effects of transfer to seawater on digestion and gut function in Atlantic salmon smolts (Salmo salar L.). Aquaculture, 90, 85-96.

Varsamos, S., Nebel, C. \& Charmantier, G. (2005). Ontogeny of osmoregulation in postembryonic fish: a review. Comparative Biochemistry and Physiology Part A: Molecular and Integrative Physiology, 141(4), 401-429.

VASEP, (2020). Total fisheries production in November 2020 reached 7.7 million tons, increased $1,7 \%$. http://vasep.com.vn/san-pham-xuat-khau/tin-tonghop/san-xuat/to-ng-sa-n-luo-ng-thu-y-sa-n-11-thangnam-2020-dat-7-7-trieu-tan-tang-1-6-17972.html (access on Mar. 23, 2021).

Worthington T. M. (1982). Enzymes and Related Biochemicals. Biochemical Products Division, Worthington Diagnostic System, Freehold, NJ, USA.

Yin, F., Peng, S. M., Sun, P. \& Shi, Z. H. (2010). Effects of low salinity on digestive enzyme activity in intestinal tract of juvenile silver pomfret Pampus argenteus. Journal of Marine Fisheries, 2. (English Abstract). 